\title{
Changes in the isoenzymes of lactic and malic dehydrogenase during the development of the frog Rana temporaria ${ }^{1}$
}

\author{
Jack N. R. Grainger and Yvette W. Kunz \\ Department of Zoology, Trinity College, Dublin, Ireland
}

\begin{abstract}
KURZFASSUNG: Anderungen der Isoenzyme von Milch- und Apfelsäure-Dehydrogenase während der Entwicklung des Frosches Rana temporaria. Es wurden verschiedene Organe adulter Grasfrösche sowie das Isoenzymmuster von Milchsäure-Dehydrogenase (LDH) und Äpfelsäure-Dehydrogenase $(\mathrm{MDH})$ im Verlauf der Ontogenie elektrophoretisch untersucht. In allen geprüften adulten Organen treten zwei Bande (I, II) der LDH verschiedener Stärke auf. Die langsamer anodenwärts wandernde Fraktion II ist in Herz, Gehirn und Ovarium schwächer, während im Skelettmuskel die Bande II eine stärkere Aktivität aufweist. Unbefruchtete Eier, 2-Zell-, 4-Zell-, Gastrula- und Neurulastadien wiesen ebenfalls zwei Bande auf. Die schwächere Bande II verschwindet im Schwanzknospen-Stadium; sie tritt erst in einem sehr späten Kaulquappen-Stadium wiederum auf, und zwar wird dieses Isoenzym in der Leber synthetisiert. Es wurde auf verschiedenen Wegen versucht, das Erscheinen von Bande II experimentell zu induzieren, nämlich durch Hormonbehandlung, verschiedene Futtergaben, Hunger und verminderten Sauerstoffdruck. Es gelang in keinem Falle, das Auftreten dieser Bande zeitlich vorzuverlegen. Eine Entwicklung bei verschiedenen, jedoch konstanten Temperaturen $\left(12^{\circ}, 20^{\circ} \mathrm{C}\right)$ führte zu keinen Veränderungen des Isoenzymmusters. Regenerierte Schwanzmuskulatur verhielt sich wie normaler Kaulquappen-Skelettmuskel. Es wird die Schlußfolgerung gezogen, daB die Synthese der LDH-Isoenzyme streng genetisch kontrolliert wird. Die MDH der Organe adulter Tiere sowie der verschiedenen Entwicklungsstadien ergab nur eine Bande. Dieses Enzym kommt somit beim Frosch nur in einer Molekülform vor.
\end{abstract}

\section{INTRODUCTION}

It is now well established that an enzyme can exist in the same tissue in a number of different varieties known as isoenzymes or isozymes; see for instance ALLEN (1961), Amelung (1961), CAHN et al. (1962). All varieties catalyse the same reaction but differ slightly in their properties and can be separated by electrophoresis. The present study is concerned with the isozymes of lactic dehydrogenase (LDH) and malic dehydrogenase $(\mathrm{MDH})$ of the adult frog, and the pattern of changes which take place in them during the course of development. We thought at first that - since enzyme synthesis is under close genetic control and certain genes become active only at certain temperatures - perhaps different isozymes would be produced if frog eggs were reared

1 This paper is dedicated to Prof. Dr. F. VERZÁr on the occasion of his 80th birthday. 
at low and high temperatures respectively. As will be seen later, this proved not to be the case.

Haupt \& Giersberg (1958) made a study of $\mathrm{LDH}$ isozymes in a variety of vertebrates and found two isozymes in amphibia (Xenopus laevis, Rana temporaria and Bufo vulgaris). The two authors illustrate in a figure two bands from heart, liver, kidney and somatic muscle tissue of Rana temporaria, apparently of equal strength, moving towards the anode. KAPLAN et al. (1960) observed slight differences in the properties of $\mathrm{LDH}$ from skeletal muscle and heart in bull frog and grass frog as regards the effect of coenzymes and their analogues as well as different concentrations of substrate. NAcE et al. (1961) using serological and electrophoretic methods claimed to have identified four different anode-moving isozymes in the oocyte of Rana pipiens. They found that the two fastest moving ones were lost by the tailbud stage. Three of the four isozymes, they claimed, were found in the adult oviduct.

\section{MATERIALS AND METHODS}

The present work was carried out on Rana temporaria obtained locally from a supplier. Adults were kept in basins in a little water at $8^{\circ} \mathrm{C}$. Most of the work was carried out on spring frogs. When eggs were required, the adults were placed in groups at room temperature in a little water. The newly laid eggs were then transferred to tauks in which the water was controlled to $\pm 0.1^{\circ} \mathrm{C}$ with mercury-toluene regulators. Some eggs were reared at room temperature. Each tank was aerated.

$\mathrm{LDH}$ and $\mathrm{MDH}$ isozymes were separated in the following way. Specimens were dried superficially on filter paper, weighed and homogenised with a glass hand homogeniser with $0.029 \mathrm{M}$ Tris buffer $\mathrm{pH} 8.9$. The homogenate was centrifuged at 7000 r. p. m. for 10 minutes in a cold room and the supernatant was applied to strips of heavy Whatman filter paper (no. 17). These were inserted into the starch gel blocks. The starch gels were made up in $0.029 \mathrm{M}$ Tris buffer pH 8.9 using Connaught starch. $0.1 \mathrm{M}$ boric acid buffer $\mathrm{pH} 8.5$ was used for the compartment solutions. Electrophoresis was carried out for 16 hours at room temperature $\left(18^{\circ}\right)$ with a voltage drop of $6 \mathrm{~V}$ per $\mathrm{cm}$. The LDH bands were visualised by the method of Markert \& Molier (1959) and MDH using the modifications suggested by Moore \& VILLEE (1963). Nitroblue tetrazolium was however replaced by neotetrazolium.

While this was primarily a qualitative study, some quantitative measurements were made to ensure that the bands staining up on the gel blocks did represent $L D H$ activity. For these tests the starch gel blocks were run in the usual way and were then sliced across into $1 \mathrm{~cm}$ strips. These were frozen for 30 minutes in a deep freeze and then thawed for 2 hours at room temperature. On squeezing, the liquid readily came out from the strips. $0.2 \mathrm{ml}$ of liquid from a strip was placed in a $1 \mathrm{~cm}$ cuvette together with $0.15 \mathrm{ml} 0.015 \mathrm{M} \mathrm{DPN}, 0.3 \mathrm{ml} 0.2 \mathrm{M}$ sodium lactate and $2.35 \mathrm{ml} 0.02 \mathrm{M}$ Tris buffer $\mathrm{pH} 8.9$, and the absorbtion followed at $340 \mathrm{mu}$ (MARKert \& Apella 1961). These tests confrrmed that the LDH activity coincided with the staining bands and was in fact confined to these bands. A considerable loss in enzyme activity was found using the above procedure. 
Malic dehydrogenase was visualised by replacing the sodium lactate with sodium malate in MARKERT \& MøLLER's (1959) method.

In view of the fact that CAHN et al. (1962) found marked differences in the sensitivity of mammalian LDH isozymes to pyruvate inhibition, we thought that this might provide a simple method for estimating each of the two frog LDH isozymes. We added sodium pyruvate to the agar obtaining the following final concentrations in the MARKERT \& Møller (1959) method: 1, 3, 5,7,10,20 and $50 \mathrm{mM.} 20$ and $50 \mathrm{mM}$ proved completely inhibitory for both isozymes. The lower concentrations affected only the fainter bands: band II was abolished in heart muscle whereas band I was abolished in skeletal muscle. We found no differential inhibitory effect.

\section{RESULTS}

In no case did more than two LDH bands stain up on the starch gel blocks. In the case of $\mathrm{MDH}$ we found only one band throughout this work. Under the conditions used the LDH bands were located at $1.5 \mathrm{~cm}$ (band II) and $5 \mathrm{~cm}$ (band I). The
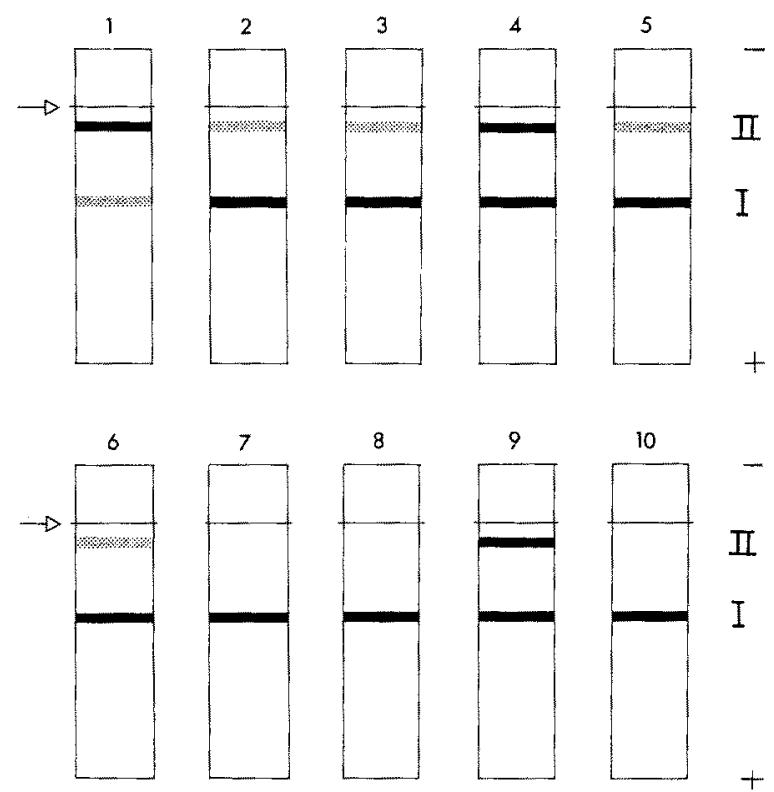

Fig. 1: Starch gel electrophoresis for lactic dehydrogenase (1-9) and malic dehydrogenase (10). (1) Adult skeletal muscle, (2) adult heart muscle, (3) adult brain, (4) adult liver, (5) adult ovary, (6) fertilized eggs, (7) tail bud stage, (8) tadpole muscle, (9) late tadpole liver, (10) tissues of adult and embryonic stages; shaded bands are fainter than black ones; the arrows denote the origin

fastest moving band is, in accordance with convention, called I and the slower moving one II. The single MDH band was located $5 \mathrm{~cm}$ from the origin. In no case was a cathode moving band found. 


\section{Lactic dehydrogenase results}

\section{Organ differences}

We found marked differences in intensity of bands I and II in the different tissues of the adult frog. This phenomenon is now well established in mammals where at least $5 \mathrm{LDH}$ bands are present. Band II was intense in skeletal muscle and liver. Band I was very strong in cardiac muscle and also strong in brain, ovary and liver (Fig. 1). There was a certain amount of variation in the relative intensity of the two bands in the case of liver. The other tissues however proved remarkably consistent.

\section{Changes during development}

In these experiments development took place at room temperature. Unfertilised eggs removed from their jelly gave the normal ovary pattern with most activity in band I and little activity in II (Fig. 1). Two cell, 4 cell and gastrula stages showed the same with almost all the activity in band I and very little in II. By the tail bud stage however band II disappears and from this stage on there is a stronger I band. There is no trace of II until much later when the hind legs appear. Then II reappears but band I is still the dominant band. In order to find out the organs in which II was being synthesized we dissected out various parts of the advanced tadpoles and ran them separately on the starch gel blocks. Heart, leg muscle and tail all showed a single band at I. Liver, however, showed two clear bands (I and II) and the rest of the body (minus tail, legs, heart and liver) gave only band $I$. It is clear that synthesis of II begins in the liver. As with the adult liver we found variation in the relative intensity of the two bands. A few metamorphosing tadpoles were examined at the beginning of metamorphosis and towards the end when the tail was largely resorbed. Again only the liver gave two bands; the rest of the body (gut excluded) gave only band I. Identification of the bands in the case of tadpole gut was unsatisfactory as it was found that the gut contents caused extensive smearing and interference with the development of clear bands.

We were not successful in getting our frogs completely through metamorphosis but a young frog weighing 5 grams caught in the wild was tested. In this individual the heart still only showed one band (I); whereas the leg muscles now had two bands of which II was the stronger, so that at this stage the skeletal muscles seem to have reached their final adult pattern. The liver showed two bands of equal strength.

\section{Effect of temperature}

Newly fertilised eggs were reared at constant temperatures of $12^{\circ}$ and $20^{\circ} \mathrm{C}$, and different stages were tested up to the late tadpole stage. At both temperatures the results were similar to those described above, and there was no qualitative difference 
or marked quantitative difference (as shown by the intensity of the bands) between the individuals reared to the same stage of development at both constant temperatures.

\section{Attempts to induce the early appearance of band II}

As was seen above band II is absent from the tail bud stage until the hind legs appeared. We carried out various experiments in an attempt to induce it.

Low oxygen concentration. Various authors (THOMAs et al. [1960], LAurer [1961]) suggested that some dehydrogenases may be more efficient under aerobic conditions, whereas others may be more efficient in an anaerobic situation. Late gastrulae which had been reared in closed containers for two weeks at room temperature (by which time they were active tadpoles) showed only band I on being tested.

Food. Very early tadpoles were divided into groups and each group was fed on a different food: liver powder, spinach, minced frog muscle, and another group was kept without food. When tested all showed the same result, namely, one LDH band in position I.

Hormones. Allen (1961) found that hormones had a very marked effect on the LDH isozymes developed in the mouse. We raised groups of early tadpoles in the presence of thyroxin, others in the presence of minced frog thyroid and others again in the presence of minced frog ovaries. On testing the LDH isozyme pattern was the same as in the controls (one band at position I).

Denervation. Brody (1965) found that when the nerve going to the leg muscles of the guinea pig was cut, the denervated muscle, when examined 11 weeks later, showed the LDH pattern characteristic of the muscle from the young animal. We cut the nerve going to the gastrocnemius muscle of the right leg in several frogs and kept them at $10^{\circ} \mathrm{C}$. On killing one frog 8 weeks later we found that the muscle was slightly reduced in size and somewhat redder in colour than the muscle on the left leg. On testing, however, both legs gave the normal adult $\mathrm{LDH}$ isozyme pattern.

Regeneration. When the tail is cut off a tadpole, it will be regenerated. We tested regenerated tails and found that, like normal tails, they showed a single band in position I.

\section{Malic dehydrogenase}

Starch gel electrophoresis of adult frog tissues showed that in skeletal muscle, ovary, liver, brain and heart muscle only one band was present (Fig. 1). The band was slightly more diffuse than either of the LDH bands. Unfertilised eggs, 4 cell stages, gastrulae and early and late tadpoles all showed a single band in the same location as in the adult although, as in $\mathrm{LDH}$, there was clearly much more enzyme present after gastrulation than before. 


\section{DISCUSSION}

Similar isozyme changes to those found during the development of the frog have been recorded in other groups of animals. MARKert \& Mølier (1959) and FlexNer et al. (1960) showed that the LDH isozymes appear and disappear during the course of mammal development. MoORE \& VILLEE (1963) observed the same phenomenon in echinoderms. FINE et al. (1963) also found this in the rabbit, cow, rat and chick.

The disappearance of $\mathrm{LDH}$ isozyme II during early frog development could be explained by the absence of synthesis. The unfertilised egg contains both I and II, which may be either synthesised in the ovum in the ovary or alternatively may be taken up from nurse cells in the ovary or oviduct. The reappearance of II in the late tadpole, first of all in the liver and later in skeletal muscle could be explained by the activation of the appropriate genes in these tissues. The fact that we were not able to activate them prematurely and thus produce the premature synthesis of II may indicate that developmental genes are responsible which are only "turned on" at the appropriate point in development. This activation may itself be under genetic control. Only in some way like this is it possible to account for the changes in skeletal muscle, which at first shows only band I, but in the adult has band II predominant with only small traces of I. Perhaps future work will elucidate the mechanism involved.

It is remarkable that rearing fertilized eggs at different temperatures seems to have no marked effect on the LDH isozymes. Changes in enzyme levels are amongst the most important alterations taking place during adaptation to temperature PRECHT, Christophersen \& Hensel (1955), Grainger (1960). It is also known that some genes (particularly in lower organisms) become active at some temperatures but not at others. So it might have been expected that some changes in isozymes would have been found when the organism develops at different temperatures. This is clearly not the case with $\mathrm{LDH}$ or $\mathrm{MDH}$. However, these are only two of a multitude of enzymes in the cells, and what applies to them may not apply to others.

\section{SUMMARY}

1. Two isozymes of lactic dehydrogenase (LDH) are present in the tissues of the frog Rana temporaria. The slow moving one (II) is abundant in adult skeletal muscle and lesser quantities are found in heart, brain and liver. The fast moving band (I) is predominant in heart muscle, liver and brain.

2. The adult ovary, unfertilized eggs, fertilized eggs and embryos at the 2 cell, 4 cell and gastrula stages show both bands but band II gradually gets fainter and disappears. From the tail bud stage until the tadpoles get their hind legs, only band I is present; the reappearance of II is due to synthesis of this isozyme in the liver during the late tadpole stage. Leg muscles at this stage show only band I. Immediately after metamorphosis however II appears in abundance in the leg muscles, and isozyme I declines relatively.

3. Various attempts were made to induce the early appearance of isozyme II during 
the tadpole stage. Low oxygen, a variety of foods, thyroid hormone and minced ovaries had no effect.

4. Rearing fertilized eggs to the tadpole stage at $12^{\circ}$ and $20^{\circ} \mathrm{C}$ produced no marked difference in the isozymes of $\mathrm{LDH}$. Denervation of the adult gastrocnemius muscle for 8 weeks had no influence on leg muscle LDH isozymes. Regenerated tadpole tail showed the same pattern as the normal tadpole tail.

5. It is concluded that the synthesis of the LDH isozymes is under very close genetic control.

6. Malic dehydrogenase seems to be a homogeneous enzyme in the frog and shows no isozyme varieties.

\section{LITERATURE CITED}

AlLEN, J. M., 1961. Multiple forms of LDH in tissues of the mouse: their specificiry, cellular localisation and response to altered physiological conditions. Ann. N. Y. Acad. Sci. 94, 937-951.

Amelung, D., 1961. Die Heterogenität von Fermenten in den Organen und im Serum. Dt. med. Wscbr. 86, 731-734.

Brody, I. A., 1965. Effect of denervation on the lactate dehydrogenase isozymes of skeletal muscle. Nature, Lond. 205, 196.

Cahn, R. D., Kaplan, N. O., Levine, L. \& Zwilling, E., 1962. Nature and development of lactic dehydrogenase. Science, N.Y. 136, 962-969.

Fine, H., Kaplan, N. O. \& Kuftrnec, D., 1963. Developmental changes of mammalian lactic dehydrogenases. Biochemistry, Wash. 2, 116-121.

Flexner, L. B., Flexner, J. B., Roberts, R. B. \& La HabA, G. De, 1960. Lactic dehydrogenases of the developing cerebral cortex and liver of the mouse and guinea pig. Devl Biol. 2, 313-328.

GRAINGER, J. N. R, 1960. The early stages in the adaptation of the frog Rana temporaria to higher temperatures. Zool. Anz. (Suppl. Bd) 24,60-72.

Haupt, I. \& GiersBerg, H., 1958. Untersuchungen über die Heterogenität und Organspezifität von Enzymen, speziell der Mildasäuredehydrogenase, innerhalb der Wirbeltierreihe. Naturwissenschaften $\mathbf{4 5}, 268-269$.

Kaplan, N. O., CiotTi, M. M., Hamolsky, M. \& Bieber, R. E., 1960. Molecular heterogeneity and evolution of enzymes. Science, N.Y. 131, 392-397.

Laufer, H., 1961. Forms of enzymes in insect development. Ann. N. Y. Acad. Sci. 94, $825-835$.

Markert, C. L. \& Møller, F., 1959. Multiple forms of enzymes: tissue, ontogenetic and species specific patterns. Proc, natn. Acad. Sci. U.S. A. 45, 753-763.

- \& Appella, E., 1961. Physico-chemical nature of enzymes. Ann. N. Y. Acad. Sci. 94, 678-690.

Moore, R. O. \& Virlee, C. A., 1963. Multiple molecular forms of malate dehydrogenases in echinoderm embryos. Comp. Biochem. Pbysiol. 9, 81-94.

NAce, G. W., SuYama, T. \& Smrth, N., 1961. Early development of special proteins. In: Symposium on germ cells and development. Instit. Internat. d'Embryol. (Fondazione A. Baselli), Pavia, 564-603.

Precht, H., Christophersen, J. \& Hensex, H., 1955. Temperatur und Leben. Springer, Berlin, $514 \mathrm{pp}$.

Thomas, E. D., Lochte, H. L., Greenough, W. B. \& Walls, M., 1960. In vitro synthesis of foetal and adult haemoglobin by foetal haemopoetic tissues. Nature, Lond. 185, 397-398. 


\section{Discussion following the paper by GRAINGER \& KUNZ}

AEBr: Der von Thnen erhobene Befund, daß durchweg nur 2 Banden beziehungsweise 2 LDHIsoenzyme gefunden wurden, ist insofern von Interesse, als bei Warmblütlern in der Regel 5 LDH-Isoenzyme existieren. Ist es denkbar, daß beispielsweise die hybriden Formen in "unterschwelliger" Konzentration vorliegen oder gilt die Hypothese von MARKERT und Möller hier nicht? Der Befund, daß beim Frosch-Gastrocnemius nach Nervendurchtrennung nicht dieselbe Änderung des Enzymmusters beobachtet werden konnte wie beim Meerschweinchen, dürtte wohl mit dem offenbar völlig verschiedenen Verhalten der LDH-Isoenzyme beim Säuger und Kaltblüter zusammenhängen. Zwischen diesen beiden Befunden braucht jedenfalls kein Widerspruch zu bestehen.

Kunz: Zum ersten Teil Ihrer Frage: Es ist wohl möglich, daß „unterschwellige“ Isoenzyme nicht erfaßt wurden. Wir glauben es jedoch nicht, da die von uns angewandte Methode sehr empfindlich ist.

Wreser: Bei Triturus cristatus kommen auch nur 2 LDH-Isozyme vor. Ob sich dieser Befund nicht so erklären ließ̧e, daß bei Amphibien zwar auch - wie bei Warmblütern - 2 Grundmolekülarten vorkommen, diese aber stets nur rein, das heißt nicht in. Mischungsverhältnissen auftreten?

Kunz: Ich glaube nicht, daß dies zutrift. Bei Xenopus (unpubliziert) haben wir beispielsweise mebrere LDH-Bande nachgewiesen.

Hess: Das Auffinden von 2 Isoenzymbanden widerspricht der geläufigen Isomerentheorie der Isoenzymstruktur. Es wäre sehr wichtig, diesen Befund durch Isolierung der Enzyme zu sichern.

Kunz: Wir haben keinen Grund anzunehmen, daß diese Theorie auch für primitive Vertebraten Gültigkeit hat. 